\title{
Revista ANDE e a defesa da escola pública: Contribuições para a constituinte.
}

\section{Renata de Cássia Araújo Cardoso*, Fabiana de Cássia Rodrigues}

\section{Resumo}

Em um período de intensificação das discussões sobre a escola pública e a democracia, emergem movimentos sociais, assim como entidades que declaram resistência à conjuntura vivida nos anos 1980. Os movimentos sociais desencadeiam uma série de outros movimentos propositivos na educação e no ensino, dando início a um processo de organização do campo educacional. Em 1979, foi criada a Associação Nacional de Educação (ANDE), com o objetivo de reunir professores, universitários, estudiosos e posteriormente intelectuais da educação para estruturar e subsidiar os debates acerca das questões educacionais e da prática pedagógica. Desta entidade surge a Revista da ANDE, que se propõe a discutir e disseminar esses debates de forma democrática e engajada na defesa da escola pública.

\section{Palavras-chave: \\ Revista da ANDE, Escola pública, Constituinte.}

\section{Introdução}

A Revista da ANDE, se apresentava disposta a construir uma revista democrática a fim de alcançar todos os níveis da educação, propondo que através do debate e da participação seria possível atuar na sociedade brasileira em busca de uma educação voltada para os interesses da maioria e identificada com os princípios da democracia e justiça social.

Os objetivos dessa pesquisa, baseada nos impressos da Revista da ANDE, foram mapear e analisar as principais propostas educacionais do período que se articularam com os debates do capítulo da educação na Constituinte de $1987 / 88$. Foi realizado um levantamento acerca dos temas educacionais abordados na Revista. Dessa forma buscou-se fazer uma leitura ampla acerca das ideias e propostas para o ensino público e suas contribuições para as políticas educacionais.

Figura 1. Capas das edições no: 1,6,9 e 20.

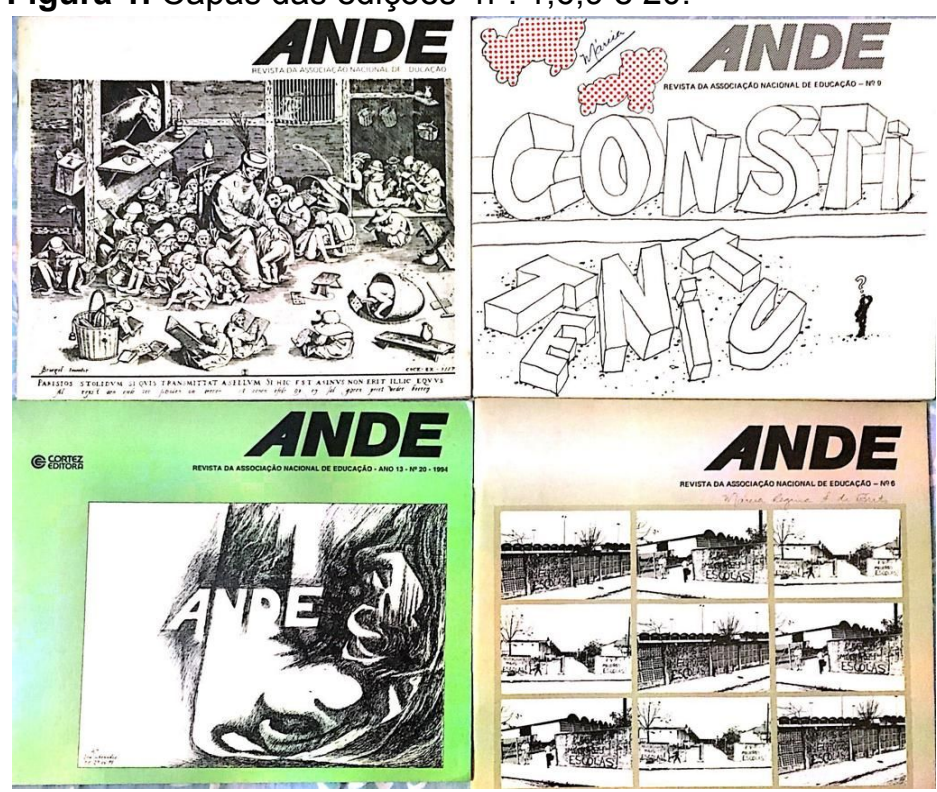

\section{Resultados e Discussão}

Foram analisadas as 21 revistas publicadas, entre 1981 e 1995. Para sistematizar os dados, utilizou-se um modelo de fichas de análise proposto por NÓVOA (2002), que possibilitou uma leitura panorâmica dos periódicos.

As temáticas mais debatidas foram: política educacional, o professor e a prática pedagógica, seguida de assuntos referentes a problemáticas do $1 .^{\circ}$ grau, gestão pública e história da educação, conteúdos que estão intimamente ligados entre si e que se encontravam em evidência, sendo articulados com diversos outros assuntos da educação. O tema comum a todos era a defesa da escola pública com 0 intuito de construir alternativas historicamente possíveis para a educação brasileira.

\section{Conclusões}

As propostas formuladas surgem a partir de uma crítica à realidade daquele momento. A Revista apresenta primeiramente um panorama dos desafios da educação no geral e críticas ao sistema de ensino brasileiro em relação à estrutura, ao investimento, à falta de democracia nos processos, à quantidade e à qualidade. A partir disso abre um debate sobre a realidade do ensino e seus possíveis encaminhamentos que contribuem para os debates em torno da nova Constituição Federal.

$\mathrm{Na}$ análise foi possível notar a busca em estabelecer uma relação entre a universidade e o ensino de $1 .^{\circ}$ e $2 .^{\circ} \mathrm{grau}$, articulando a teoria academicamente produzida pelas universidades e a prática diária vivida pelos professores do ensino básico; propostas para a participação e conscientização dos professores, contextualizando historicamente a escola pública, a educação e a democracia. Levanta, desse modo, indagações que culminam em proposições quanto a: formação de professores, democratização do acesso e conteúdos escolares.

ANDE, Revista da Ande. São Paulo: CORTEZ, 1981-1995, n. 1 ao 21.

NÓVOA, A.; BANDEIRA, F.; PAULO, J.C., TEIXEIRA, V.. A imprensa de educação e ensino: concepção e organização do repertório português. In. CATANI, Denice Barbara; BASTOS, Maria Helena Camara (org.). Educação em Revista: a Imprensa Periódica e a História da Educação. São Paulo: Escrituras, 2002. 